\title{
OVÍDIO, AMORES, I.9
}

TRADUZIDO POR DANIEL DA SILVA MOREIRA 


\title{
OVÍDIO, AMORES, I.9
}

\author{
Daniel da Silva MOREIRA ${ }^{1}$ \\ Doutorando em Letras - Estudos Literários \\ Universidade Federal de Juiz de Fora (UFJF) \\ Juiz de Fora, Minas Gerais, Brasil \\ moreiradsm@gmail.com
}

Militat omnis amans et habet sua castra Cupido;

Attice, crede mihi, militat omnis amans.

Quae bello est habilis, Veneri quoque conuenit aetas.

Turpe senex miles, turpe senilis amor.

Quos petiere duces animos in milite forti,

Hos petit in socio bella puella uiro.

Peruigilant ambo; terra requiescit uterque:

Ille fores dominae seruat, at ille ducis,

Militis officium longa est uia: mitte puellam,

Strenuus exempto fine sequetur amans;

Ibit in aduersos montes duplicataque nimbo

Flumina, congestas exteret ille niues,

Nec freta pressurus tumidos causabitur Euros

114 Aptaque uerrendis sidera quaeret aquis.

Quis nisi uel miles uel amans et frigora noctis

Et denso mixtas perferet imbre niues?

Mittitur infestos alter speculator in hostes;

In riuale oculos alter, ut hoste, tenet.

Ille graues urbes, hic durae limen amicae

Obsidet; hic portas frangit, at ille fores.

Saepe soporatos inuadere profuit hostes

Caedere et armata uulgus inerme manu;

Sic fera Threicii ceciderunt agmina Rhesi

Et dominum capti deseruistis equi;

Saepe maritorum somnis utuntur amantes

Et sua sopitis hostibus arma mouent.

Custodum transire manus uigilumque cateruas

Militis et miseri semper amantis opus.

Mars dubius nec certa Venus; uictique resurgunt,

Quosque neges umquam posse iacere, cadunt.

Ergo desidiam quicumque uocabat amorem,

Desinat; ingenii est experientis amor.

Ardet in abducta Briseide maestus Achilles;

Dum licet, Argiuas frangite, Troes, opes.

Hector ab Andromaches conplexibus ibat ad arma,

Et, galeam capiti quae daret, uxor erat.

Summa ducum, Atrides, uisa Priameide fertur

Maenadis effusis obstipuisse comis.

Mars quoque deprensus fabrilia uincula sensit;

Notior in caelo fabula nulla fuit. 
Ipse ego segnis eram discinctaque in otia natus;

Mollierant animos lectus et umbra meos;

Inpulit ignauum formosae cura puellae

Iussit et in castris aera merere suis.

Inde uides agilem nocturnaque bella gerentem.

Qui nolet fieri desidiosus, amet! ${ }^{2}$

Todo amante é soldado, e Cupido tem sua caserna;

Ático $^{3}$, creia em mim, todo amante é soldado.

A idade própria à guerra também a Vênus convém.

Torpe é o velho soldado e torpe o amor senil.

$\mathrm{O}$ ânimo que exige um general de um bravo soldado

É o que a bela mulher exige de seu homem.

Ambos velam toda a noite e os dois repousam no chão,

Um guarda as portas de sua dama, o outro as do líder.

Ser soldado requer longas marchas, afaste a amada

Que o amante extremoso a seguirá até o infinito.

Marchará contra altos montes, por rios aumentados

Com chuva e se erguerá na neve acumulada.

Singrando os mares, não pretextará o túmido Euro ${ }^{4}$,

Nem, varrendo as águas, buscará astros propícios.

Quem, senão o soldado ou o amante, suportará

$\mathrm{O}$ frio da noite e a neve unida à densa chuva?

Um a inimigos hostis como espião é enviado;

O outro os olhos mantém no rival inimigo.

Aquele urbes grandes tomará, este o umbral da dura

Amiga; este portas parte, aquele portões.

Já foi útil invadir o inimigo adormecido

E o vulgo inerme de mão armada abater.

Assim, as feras tropas do trácio Reso caíram

E os cavalos cativos seu senhor deixaram ${ }^{5}$.

De fato, os amantes usam o sono dos maridos

E, adormecido o inimigo, movem suas armas.

Cruzar catervas de guardiões e tropas de vigias

É sempre obra do soldado e do amante mísero.

Marte é dúbio e Vênus incerta; os vencidos ressurgem,

$\mathrm{E}$ os que negarias poderem jazer, caem.

Assim, todo aquele que chamava o amor de indolência,

Que se cale. O amor é de engenho experiente.

Arde pela raptada Briseida o triste Aquiles;

Troianos, sujeitai, se é lícito, os argivos ${ }^{6}$ !

Heitor ia dos abraços de Andrômaca até as armas

E o capacete à cabeça a esposa lhe dava ${ }^{7}$.

O sumo líder, o Atrida $^{8}$, ao ver Priameide ${ }^{9}$, dizem,

Encantaram-no os vastos cabelos de mênade ${ }^{10}$.

Marte, surpreso também, sentiu os grilhões forjados ${ }^{11}$;

No céu nenhuma história foi mais conhecida.

Eu próprio era inerte e nascido pros ócios distintos; 
O leito e a sombra amoleceram meus ânimos.

$\mathrm{O}$ amor de formosa moça estimulou o inútil

E me ordenou ganhar cobres nas suas casernas.

E assim me vês ágil e animoso em noturna guerra.

Quem não quiser ser feito desidioso, que ame!

\section{REFERÊNCIA BIBLIOGRÁFICA:}

OVIDE. Les Amours. Texte établi et traduit par Henri Bornecque. Paris: Les Belles Letres, 2005.

1 Lattes Daniel da Silva Moreira. Disponível em: http://lattes.cnpq.br/0587343464722458

2 Texto latino proveniente de: OVIDE. Les Amours. Texte établi et traduit par Henri Bornecque. Paris: Les Belles Letres, 2005.

${ }^{3}$ Este Ático, a quem a elegia toma por destinatário, é tradicionalmente identificado como Cúrsio Ático (também mencionado nas Pônticas, II.4 e II.7), um cavaleiro de alta posição que acabou arruinado por Sejano, o braçodireito de Tibério.

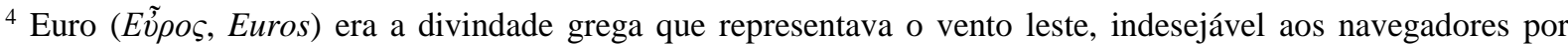
trazer tempestades. Seu símbolo era um vaso invertido, derramando água.

${ }^{5}$ Reso era um rei da Trácia que teria lutado ao lado dos troianos na guerra de Tróia. No livro X da Ilíada, Diomedes e Odisseu, depois de matarem o rei e seus homens, roubaram seus preciosos cavalos durante uma

116 invasão noturna a seu acampamento. o que permite que os troianos tenham um período de sucesso sobre os gregos, ou argivos.

${ }^{7}$ Heitor era filho de Príamo, o rei de Tróia, e Andrômaca sua esposa.

${ }^{8}$ Agamêmnon.

${ }^{9}$ Referência a Cassandra, filha de Príamo, que foi tomada por Agamêmnon como espólio de guerra quando Tróia caiu.

${ }^{10}$ As mênades são sacerdotisas de Dionísio e uma de suas características físicas são os cabelos desalinhados, tais como estavam os de Cassandra ao ser dada a Agamêmnon.

${ }^{11}$ Marte, na mitologia, mantinha relações secretas com Vênus, esposa de Vulcano, o deus romano do fogo e da metalurgia. Vulcano expôs a ligação ilícita de Marte e Vênus preparando uma armadilha feita de uma fina rede metálica com que capturou os dois e os exibiu no Olimpo aos outros deuses.

RECEBIDO EM: 28 de junho de 2015

ACEITO EM: 30 de julho de 2015 